\title{
A QUESTÃO DA COMPETÊNCIA TÉCNICA PARA O ASSISTENTE SOCIAL
}

\author{
JOLINDA DE MORAES ALVES 1
}

ALVES, J.M. A questão da competência técnica para o assistente social. Semina: Ci. Soc JHum., Londrina, v. 13, n. 3, p. 148-157, set. 1992.

RESUMO: Este artigo trabalha a "competência profissional" do assistente social, enfatizando suas dimensóes técnica $\theta$ poltuca. Para tanto contempla: o papel e a inserção da profissão na divisão sócio-têcnica do trabalho, bcalizada no setor de serviços do atual estágio monopolista do capitalismo; o saber institufdo do assistente social no interior das instituiçbes de bem estar social, a partir das suas atribuiçōes, instrumentos e técnicas; a contradiçáo de uma profissáo que tem vinculos empregat/cios com organismos criados pelo Estado e pelo Capital, mas que deve prestar serviços a usuários subalternizados; e o efetivo compromisso com o atendimento à demanda social cobcada pelo usuáno institucional.

PALAVRAS-CHAVE: Competência profissional; Assistente social; Trabalho; Instrumento; Técnica; Polftica; Compromisso; Serviços Sociais; Estado; Capitalismo; Questăo social

\section{1 - A COMPETÉNCIA PROFISSIONAL DO AS- SISTENTE SOCIAL E A DIVISÃo SÓCIO TÉCNICA DO TRABALHO:}

As atividades profissionais desenvolvidas pelos Assistentes Sociais têm determinaçāo histórica comprometida com o enfrentamento da "questão social"2 emergente das relaçōes sociais nas sociedades capitalistas.

$A$ análise que se faz quanto às necessidades humanas, extrapola o nivel biológico de sustentação da vida, para o surgimento das necessidades sociais, económicas, culturais e politicas, configuradas nas relaçōes dos homens em sociedade.

Faz-se necessário, portanto, tecer algumas consideraçōes sobre as relaçōes sociais entre os homens a partir das atividades de trabalho, no sentido de melhor evidenciar o surgimento das necessidades humanas que provocam o agravamento da "questão social", foco de intervenção do Serviço Social.

Pelo trabalho, os homens se relacionam para transformar a natureza, de forma a assegurarem sua sobrevivência, através da satisfação de suas necessidades básicas.

O processo de trabalho vital para os homens e sua organização é histórica, de acordo com as necessida- des emergentes em cada época. Pela organização do processo de trabalho, os homens determinam as relaçōes sociais entre si e a organização de sua cultura.

Para MARX (1987) existe intencionalidade no trabalho do homem, uma vez que ele exerce dominio sobre a natureza, imprimindo-lhe forma útil para a sua sobrevivência.

"O trabalho é um processo de que participam o homem e a natureza, processo em que o ser humano, com sua própria açăo impulsora, regula e controla seu intercambio material com a natureza. Pó em movimento as forças naturais de seu corpo, braços e pernas, cabeça e máos, a fim de apropriar-se dos recursos da natureza imprimindo-lhes forma citil a vida humana. Atuando assim sobre a natureza externa e modificando-a, ao mesmo tempo modifica sua propria natureza. Desenvolve as potencialidades nela adormecidas e submete ao seu dominio o jogo das forças naturais". (MARX, 1987, p. 202)

O trabalho, portanto, e dependente da vontade do homem, diante de suas necessidades ao transformar a natureza.

Evidencia-se af a racionalidade da ação humana,

1 - Departamento de Serviço Social/CESA - Universidade Estadual de Londrina, Caixa Postal 6001, Londrina - Paraná - Brasil, CEP 86051-970

2 - Entende-se por questão social, a configuraçăo das desigualdades sociais, determinadas pelo modo de produção capitalista de mercadorias, que produzem efeitos contraditórios na sociedade e geram necessidades de toda ordem - sociais, económicas, culturais. politicas....- 
que supera o trabalho animal, na previsão de um resultado almejado e no imprimir um objetivo voluntário à sua ação de transformação da natureza.

"Uma aranha executa operaçסes semelhantes as do tecelato e a abelha supera mais de um arquiteto ao construir sua colmóia. Mas o que distingue o pior arquiteto da molhor abelha é que ole figura na mento sua construçăo antes de transformá-la em realidade". (MARX, 1987, p. 202)

A natureza humana pressupōe uma ação projetada, na medida em que a vontade e a imaginaçāo precedem a pura e simples atividade de trabalho. A vontade e o projeto para a açăo, por sua vez, dāo condiçāo de dominio do homem sobre as forças naturais, transformando seus recursos em bens úteis à vida humana.

Diante do exposto, coloca-se claramente a condiçāo de "sujeito", inerente ao homem, em sua relaçăo com a natureza, através do trabalho.

Segundo MARX (1987) os elementos componentes do processo de trabalho são: o próprio trabalho latividade adequada a um fim), a matéria a que se aplica o trabalho (o objeto do trabalho) e os meios de trabalho to instrumental de trabalho).

Interessa a este estudo, que trata da competéncia profissional do assistente social, considerar os dois primeiros elementos e ater-se ao terceiro - os instrumentos do trabalho -, que se refere as formas pelas quais o homem leva a cabo seu projeto de trabalho, para atingir seus objetivos de transformação da natureza. $O$ instrumento de trabalho utilizado pelo sujeito considerado como intermediário, como viabilizador do projeto imaginário e racional, que coloca o sujeito em relação com o objeto, diante do real e concreto a ser modificado.

A intencionalidade do sujeito se torna realidade a medida em que elege e se utiliza de meios capacitadores e instrumentalizadores da açăo sobre a realidade, a partir de seu projeto imaginário.

Colocada a questāo do processo de trabalho para o âmbito das profissōes, evidencia-se igualmente a intencionalidade humana em projetar formas para a construçăo da sociedade, de acordo com as necessidades surgidas nas relaçōes sociais.

A profissăo exercida pelos assistentes sociais tem significado histórico a partir da configuraçăo do modo de produçăo capitalista, principalmente no seu estágio monopolista, quando se evidencia um agravamento nos efeitos da "questão social".

No estágio monopolista do capitalismo, aumenta o papel do Estado em relaçāo à provisão do bem estar. A lógica para eriaçăo dos serviços sociais fundamenta-se nāo somente na necessidade de reprodução da classe trabalhadora consequente manutençăo do próprio sistema produtivo, como também na condiçăo de ampliaçăo do consumo de bens e serviços produzidos.

A consolidaç5o das pollticas sociais cria espaços para a atuaçăo de grupos profissionais especializados, como os assistentes sociais, que têm o trabalho alocado no setor terciário da economia, ou seja, o setor de serviços.

O capitalismo monopolista, ampliando o mercado para a esfera internacional - internacionalização do capital - historicamente amplia o setor de serviços. Assim como aumenta em larga escala o mercadejamento, aumenta o extrato humano desqualificado, desamparado e dependente, dando origem à questão social moderna, enquanto resultante das alteraçōes económicas e sociais do processo de produçāo.

O setor de serviços, em consequéncia, passa de um setor qualificado, especializado, cujo trabalho é bem remunerado e prestado diretamente ao capitalista - para um setor desprivilegiado e que, cada vez mais, tem oferta de mão-de-obra excedente do processo produtivo. 0 alargamento do setor terciário passa a exigir a ampliação das instituiçōes prestadoras de serviços, pois, embora pela natureza e conteúdo continue sendo serviço, por determinação histórica, passa a ter papel de contribuição no processo de acumulação capitalista.

Considerado enquanto rentável, o produto do trabalho do setor de serviços coloca para os assistentes sociais um tema de reflexáo: a forma social do trabalho assumida pelo Serviço Social, na era do capitalis mo monopolista.

Esta categoria - forma social - que merece nossa reflexāo enquanto assistentes sociais atuantes na sociedade capitalista de produção foi desenvolvida por BRAVERMAN (1981). A questảo se coloca, quando se observam as mudanças sócio-económicas provocadas pela centralizaçăo do capital a nivel da utilidade do trabaiho para o capitalismo monopolista, ou seja, não importa tanto o tipo de trabalho, o que interessa ao grande capital é a forma que o trabalho assume.

Baseada nesta análise, KARSCH (1987, p. 161) elaborou sua produçāo teórica, voltando-se nāo somente para o resgate da forma social que vem assumindo a profissão do Serviço Social, em sua prática cotidiana vinculada às instituiçōes e organizaçōes sociais, como igualmente à reflexão teórica do profissional de Serviço Social no tocante à percepção desta mesma forma social de trabalho.

O Serviço Social é uma profissão que nasce enraizada na questão social, que envolve os "menos favorecidos" ou os mais espoliados e tem sancionado seu exerclcio profissional, pelas instituiçōes e/ou programas de bem-estar social de natureza pública ou privada. Sua história e sua trajetória na sociedade capitalista de produçăo acompanha, contribui e serve politicamente à sua finalidade.

Essa utilidade politica tem-se evidenciado enquanto traço comum às atividades do setor de serviços. Nesse setor, para que uma prática seja satisfatória, ou ainda, para que nela se reconheçam a qualidade e eficiência, necessário identificar as funçōes sociais que ela po- 
Sobre este pressuposto de neutralidade, erigiu-se um altar ao Capitalismo. Não se percebeu, ou não se quis perceber, que toda ciência, técnica ou planejamento corresponde a uma visão de mundo - ideologia - e que, por isto mesmo, está comprometida com a classe que tem o poder nas mãos.

GORZ (1979, p. 81), afirma que até princlpios de 1960 , os marxistas também cometiam este erro de avaliação, pois "consideravam as forças produtivas - em particular as ciências e a técnica - como ideologicamente neutras e seu desenvolvimento como intrinsecamente positivo".

\section{3 - O CAPITALISMO NO BRASIL}

O Brasil foi descoberto em um momento histórico no qual o capital comercial se expandia avidamente buscando, com ansiedade, obter lucros cada vez maiores. Era a burguesia que procurava se consolidar como classe detentora do poder económico e, para conseguir seu intento, lançava mão de todos os meios.

Esse furor em busca do lucro näo media sacriffcios, năo tinha limites, não hesitava em dilapidar, vilipendiar, explorar às últimas consequéncias as novas terras descobertas.

A história do Brasil é uma história onde essa exploração está presente em todas as suas configuraçōes: metrópole/colónia; colonizador/colonizado; proprietário/escravo; patrão/assalariado.

Interessa-nos, nesse capitulo, procurar entender os determinantes politicos e económicos que nortearam a implantaçăo do capitalismo no Brasil.

Bastante rica nos pareceu a análise feita por MELLO (1988) a respeito do desenvolvimento económico brasileiro. Buscou o autor, nesta análise, duas perspectivas: a interna e a externa. Condiçōes históricas particulares, peculiares do pais em questäo e condiçōes macro-estruturais que säo fatores de influência, mas não suficientes para condicionar de maneira absoluta o direcionamento evolutivo de uma dada economia.

O autor procura explicar a implantação de um capitalismo tardio, partindo da proposta de uma periodizaçāo onde o momento anterior contém os germes do próximo; onde elementos antagónicos se interpenetram, se interinfluenciam e produzem um novo sistema. fruto de um aparente, mas só aparente antagonismo. Antagonismo mais de forma que de essência.

Esta periodizaçăo: Economia Colonial, Economia Mercantil - escravista cafeeira colonial-, e Economia Exportadora (retardarária nas suas 3 fases: nascimento e consolidaçāo da grande indústria, industrializaçäo restringida e industrialização pesada) permite que se repense a história latino-americana sob um outro ângulo: "como formação e desenvolvimento do modo de produção capitalista". (MELLO, 1988, p. 27)

Sob um ponto de vista ortodoxo, ficaria diffcil caracterizar a Economia Colonial Escravista como capitalista, jấ que nela não está presente a categoria salário como fato explicativo da exploraçâo do trabalho pelo capital. Contudo, foi buscando as peculiaridades da formação económico-social brasileira que o autor afirma: "no sistema colonial de produçâo há, formalmente, capitalismo porque a escravidão escravidão introduzida pelo capital...". (MELLO, 1988, p. 44)

Este capitalismo, podemos afirmar, tlpico do Brasil e atrasado em relaçăo ao estágio em que se en. contrava o capitalismo europeu e norte-americano tinha sua razāo de ser: os acordos económicos entre Portugal e Inglaterra impediram que aquele desenvolvesse uma burguesia industrial.

Enquanto, no séc. XVIII, a Inglaterra passava por uma revolução que daria novos rumos à sua economia, Brasil e Portugal, metrópole e colónia, igualmente espezinhados permaneciam atrasados em relação ao que ocorria com o capitalismo dos paises mais adiantados.

Se nossa economia permanecia agrária e escravista, era porque, de certa maneira, satisfazia aos interesses do capital mercantilista que sustentava esta estrutura.

Quando, em 1889, foi proclamada a República, um ano apenas após a aboliçäo da escravatura, foram dois sistemas que passaram por transformações.

O económico, que já estava preparado para absorver a mudança e introduzir o trabalho assalariado, e o politico que instaurou a República, um sistema de governo baseado na representatividade popular, mas onde o povo parece ter sido pego de surpresa, como afirma BASBAUM (1981).

Para que a República fosse proclamada, foi necessária a uniāo de duas vertentes: uma liberal, defendendo o federalismo e o individualismo e outra positivista que defendia o centralismo e era a que influenciava o exército.

O perfodo de consolidação da República foi diffcil, conturbado, repleto de embates entre estas duas correntes de pensamento, mas o corte que nos interessa aqui é aquele que aponta para o inicio efetivo da industrialização no pals e para a formação de um empresariado nacional. Foi de 1888 a 1933 que nasceu e se consolidou o capital industrial. (Apenas para uma visão do macro, cumpre enfatizar que entre 1880-1900 foi o momento de emergência do capital monopolista, em termos mundiais).

Portanto, quando começamos a engatinhar no sentido de implantar o capitalismo industrial, este mesmo capitalismo, na Europa e Estados Unidos, formava cartéis e lançava seus tentáculos sobre outras regibes do mundo se transmutando em monopolista.

Como já foi referido, MELLO analisou o desenvolvimento económico brasileiro partindo do pressuposto que o periodo anterior continha os germes do posterior. Assim, afirma ele:

*o complexo exportador cafeciro, ao acumukar, gerou o capitatdinhoiro que se transformou em capital industrial e criou as condiçbes necessárias a essa transformaçáo: uma oferta abundante no mercado de trabalho e bens de consumo e capitais..." (MELLO, 1988, p. 101) 
que supera o trabalho animal, na previsảo de um resulta. do almejado e no imprimir um objetivo voluntário à sua ą̧āo de transformaçăo da natureza.

"Uma aranha executa operacoes semelhanles ds do tecolăo e a abelha supera mais de um arquiteto ao construir sua colmelia. Mas o que distingue o pior arquiteto da melhor abelha é que ele figura na mente sua construçăo antes de transformála em realidade". (MARX, 1987, $p$. 202)

A natureza humana pressupōe uma ação projetada, na medida em que a vontade e a imaginaçāo precedem a pura e simples atividade de trabalho. A vontade e o projeto para a ação, por sua vez, dão condiçāo de dominio do homem sobre as forças naturais, transformando seus recursos em bens úteis à vida humana.

Diante do exposto, coloca-se claramente a condição de "sujeito", inerente ao homem, em sua relaçăo com a natureza, atraves do trabalho.

Segundo MARX (1987) os elementos componentes dó processo de trabalho são: o próprio trabalho (atividade adequada a um fiml, a matéria a que se aplica o trabalho (o objeto do trabalho) e os meios de trabalho lo instrumental de trabalhol.

Interessa a este estudo, que trata da competência profissional do assistente social, considerar os dois primeiros elementos e ater-se ao terceiro - os instrumentos do trabalho -, que se refere às formas pelas quais o homem leva a cabo seu projeto de trabalho, para atingir seus objetivos de transformação da natureza. O instrumento de trabalho utilizado pelo sujeito é considerado como intermediário, como viabilizador do projeto imaginário e racional, que coloca o sujeito em relação com o objeto, diante do real e concreto a ser modificado.

A intencionalidade do sujeito se torna realidade a medida em que elege e se utiliza de meios capacitadores e instrumentalizadores da ação sobre a realidade, a partir de seu projeto imaginário.

Colocada a queståo do processo de trabalho para o âmbito das profissōes, evidencia-se igualmente a intencionalidade humana em projetar formas para a construçăo da sociedade, de acordo com as necessidades surgidas nas relaçōes sociais.

A profissão exercida pelos assistentes sociais tem significado histórico a partir da configuraçāo do modo de produção capitalista, principalmente no seu estágio monopolista, quando se evidencia um agravamento nos efeitos da "questảo social".

No estágio monopolista do capitalismo, aumenta o papel do Estado em relaçāo à provisăo do bem estar. A Iógica para eriação dos serviços sociais fundamenta-se năo somente na necessidade de reprodução da classe trabalhadora e consequente manutençăo do próprio sistema produtivo, como também na condição de ampliação do consumo de bens e serviços produzidos.

A consolidaçăo das políticas sociais cria espaços para a atuaçăo de grupos profissionais especializados, como os assistentes sociais, que têm o trabalho alocado no setor terciário da economia, ou seja, o setor de servicos.

O capitalismo monopolista, ampliando o mercado para a esfera internacional - internacionalização do capital - historicamente amplia o setor de serviços. Assim como aumenta em larga escala o mercadejamento, aumenta o extrato humano desqualificado, desamparado e dependente, dando origem à questāo social moderna, enquanto resultante das alteraçōes económicas e sociais do processo de produçāo.

O setor de serviços, em consequencia, passa de um setor qualificado, especializado, cujo trabalho é bem remunerado e prestado diretamente ao capitalista - para um setor desprivilegiado e que, cada vez mais, tem oferta de mão-de-obra excedente do processo produtivo. 0 alargamento do setor terciário passa a exigir a ampliação das instituiçōes prestadoras de serviços, pois, embora pela natureza e conteúdo continue sendo serviço, por determinação histórica, passa a ter papel de contribuiçăo no processo de acumulação capitalista.

Considerado enquanto rentável, o produto do trabalho do setor de serviços coloca para os assistentes sociais um tema de reflexão: a forma social do trabalho assumida pelo Serviço Social, na era do capitalismo monopolista.

Esta categoria - forma social - que merece nossa reflexāo enquanto assistentes sociais atuantes na sociedade capitalista de produçâo foi desenvolvida por BRAVERMAN (1981). A questão se coloca, quando se observam as mudanças sócio-económicas provocadas pela centralização do capital a nivel da utilidade do trabalho para o capitalismo monopolista, ou seja, nāo importa tanto o tipo de trabalho, o que interessa ao grande capital e a forma que o trabalho assume.

Baseada nesta análise, KARSCH (1987, p. 161) elaborou sua produçăo teórica, voltando-se năo somente para o resgate da forma social que vem assumindo a profissão do Serviço Social, em sua prática cotidiana vinculada às instituiçōes e organizaçōes sociais, como igualmente à reflexảo teórica do profissional de Serviço Social no tocante à percepção desta mesma forma social de trabalho.

O Serviço Social é uma profissão que nasce enraizada na questāo social, que envolve os "menos favorecidos" ou os mais espoliados e tem sancionado seu exercicio profissional, pelas instituiçōes e/ou programas de bem-estar social de natureza pública ou privada. Sua história e sua trajetória na sociedade capitalista de produçăo acompanha, contribui e serve politicamente à sua finalidade.

Essa utilidade polftica tem-se evidenciado enquanto traço comum às atividades do setor de serviços. Nesse setor, para que uma prática seja satisfatória, ou ainda, para que nela se reconheçam a qualidade e eficiência, 6 necessário identificar as funçōes sociais que ela po- 
de e deve desempenhar na sociedade atual.

Segundo OFFE (1987, p. 136-139), o trabalho no setor de serviços tem sua funçäo sempre orientada para a manutenção das "condiçōes normais" da sociedade, com tarefa de defender, preservar e mediar os elementos diferenciados da estrutura social. Tal tarefa é entendida pelo autor a partir de dois aspectos: a "especificidade do caso" e a "generalidade da norma".

O primeiro aspecto trata do reconhecimento das particularidades, da individualidade, da contingéncia e da variabilidade de cada situação de necessidade da clientela que recebe os serviços. O segundo aspecto trata de garantir as normas, as regras e regulamentos, de acordo com os valores gerais para manutençāo das condiçōes da normalidade social.

A partir desses dois aspectos, segundo OFFE (1987), o critério de qualidade do trabalho em serviços é que ele nảo suprima a individualidade e a especificidade da situação de um "caso" em favor de uma norma de referência rfgida, nem inversamente, atribua uma tal importáncia às particularidades que as condiçōes normais previstas por terceiros não sejam realizadas. Essa incumbência caracterlstica dos trabalhadores de serviços, talvez seja melhor compreendida através de conceitos como trabalho de "sintetizaçăo", de "mediação" ou de "normalização".

Diante disso, a funçāo social do trabalho, no setor de serviços está sujeita a um duplo dilema. O primeiro dilema ocorre a nivel individual de prestação de serviços em situaçōs especlficas em que os serviços prestados serăo adequados, à medida em que considerarem adequadamente os componentes noma e caso, cuja relaçāo ê mais ou menos indefinida e, portanto, cada caso deve ser decidido a partir da necessidade de autonomia e flexibilidade, atravês da subordinaçāo a orientaçōes normativas, à experiência, à ética profissional, às capacidades de interação especifica e às qualificaçōes sociais.

O segundo dilema ocorre a nivel organizacional e resulta do fato de que as atividades em serviços săo desempenhadas como trabalho contratual. Quando isso, de fato, acontece, os critérios da racionalidade da organizaçāo (eficácia, eficiência, controle) chocam-se com as necessidades de autonomia e flexibilidade engendradas pelo primeiro dilema.

Para OFFE (1987, p. 139), esse problema tem sido muitas vezes descrito e analisado como um dilema estrutural entre orientação e mecanismos burocráticos profissionais.

O dilema será resolvido, segundo o autor, se os serviços forem considerados adequados. Os serviços, por sua vez, somente serảo considerados adequados à medida que cumprirem sua funçāo social.

No caso do Serviço Social, o dilema se evidencia da mesma forma, por que o profissonal é contratado pelas instituiçōes prestadoras de serviço social para atender às necessidades de uma clientela que apresenta uma demanda especifica.
A noção da competência profissional, portanto, estará referida a quem contrata os serviços e a quem se utiliza desses mesmos serviços. Como se viu, ocorre entre estas duas demandas um campo de possibilidades desde a harmonia até o conflito. Isto significa que o que é competente ou adequado como resposta a uma destas demandas, de salda, não o é necessariamente à outra.

Esse dilema coloca uma dualidade na questão da análise da competência profissional do assistente social, pois, pode ser referida ao componente institucional/organizacional ou ao demandado pelo usuário. A competência institucional é determinada pelo papel institucional contratado para realizar a distribuiçăo dos recursos com eficiéncia (generalidade da norma). A demandada é determinada pelas reais necessidades do usuário que, na maioria das vezes, exigiria maiores recursos da própria instituição (especialidade do caso). A dualidade leva o profissional ao dilema que faz dele um selecionador da miséria, diante de recursos insuficientes para o atendimento real e total da demanda posta.

A partir disto a questăo se coloca entre a competência profissional que produz:

- num patamar ideal, a resolução das necessidades considerando a especificidade do caso em coeréncia com a generalidade de norma.

- num patamar real numa modulação do grau de atençāo ou respostas à necessidade demandada em combinaçāo com uma modulação da generalidade da norma. Esta modulaçăo trabalha de um lado com a legitimidade da necessidade; e de outro, com a legalidade da norma. Neste campo o assistente social multiplica as estratégias e táticas, que văo desde a manipulação de norma - entrando no carnpo do clandestino da transgressão da norma - à manipulaçăo da qualidade da resposta. Neste último caso pode combinar medidas de parcializaçăo e precarização da atenção, com a retórica ou o discurso interpretativo que, pela palavra, busca o assentimento e a cumplicidade com a nảo resposta.

O Serviço Social pode ser considerado como qualquer outra profissão técnica localizada no setor de serviços porque é um custo de produção, ou seja, não vai interessar ao capitalismo monopolista a distinçăo entre o trabalhador de escritório, de manutenção, ou o assistente social. O que importa que qualquer um deles, consciente ou não, é utilizado para aperfeiçoar, controlar e manter a ordern estabelecida, se caracteriza por efetivar um tipo de trabalho que amplia o capital, embora não participe diretamente na produçāo de mercadorias.

GORZ (1980, p. 172), realizou um estudo sobre o papel dos técnicos na realidade capitalista, onde considera que os trabalhadores técnicos se diferem dos trabalhadores empregados nas indústrias năo apenas pelo seu enquadramento sindical, pelo nivel de remuneraçäo, pelo nivel de formaçăo escolar e profissional, mas, principalmente, pela liberdade no próprio trabalho e pelo poder exercido por meio desse trabalho.

Tal autonomia é proveniente do saber especializa- 
do que coloca os técnicos hierarquicamente numa posição superior aos demais empregados. $O$ poder exercido por meio desse trabalho advém do poder de inovação daqueles que concebem novas idéias, novos objetos, novos projetos. A liberdade e autonomia encontram-se circunscritas no campo de atuaçāo de cada categoria de técnicos. Quando eles dominam um determinado campo profissional, porque detem o saber especlfico sobre a melhor forma de seu funcionamento, thes concedida relativa autonomia de trabalho, uma vez que são criados para projetar e inovar aquele setor especlfico.

O campo de ação do assistente social enquanto trabalhador têcnico decorre fundamentalmente, da inserção dos serviços sociais como Polftica Social, na relaçăo capital-trabalho.

\begin{abstract}
"O desenvolvimento capitalista alcança o seu patamar mais allo na ondem monopolica que traveja a sociedado burguesa consolidada e madura. $A$ institucionalidade sobio-pollica que the es propria náo redunda imediatamente das exigencias económicas do dinamismo do capital mono polista, mas se produz como resultante do movimento das classes sociais e suas projeços. Nela, o Estado joga um papel central e especifi$c o$, dado que the cabe assegurar as condiços da reproduçáo social no ámbito da Kgica monopolica ao mesmo tempo em que deve legitimarse para além desta fronteira - donde o potenciamento do seu traço intervencionista e sua relativa permeabilidade a demandas contra-monopolista incorporadas seletivarnente com a ten dencia de neutralizá-las. Este núcleo elementar de tensóes e conilitos aparece organizado na modalidade t́pica de intervençáo sobre a "questho sociar, conformada nas pollicas sociais intervenço que a fragmenta em problemas automizados, mas que se realiza sistemática, continua e estrategicamente, em respostas que transcendern krgamente os imites da coerçáo sempre presente. Para uma tal intervençăo, requerem-se agentes técnicos especializados novos profissionais, que se inserem em espaços que amplam e complexificam a divisáo sócio (e tecnica) do trabalho. Entre estes novos atores, colocam-se os assistentes sociais: a eles se abcam funçбes executivas na implementaçáo de polticas sociais setoriais, com o entrentamento (atravess de modiacoos institucionatorganizativas) de problemas sociais, numa operaçăo em que se combinam dimensóes prático-emplicas $e$ simbolicas determinadas por uma perspectiva macroscopica que ultrapassa e subordina a intencionalidade das agencias a que se vinculam os abres. (NETO, 1991, p. 65:66)
\end{abstract}

Toda politica social brasileira tem um segmento de assistencial e, porisso mesmo, o profissional é absorvido nas diferentes érees ou setores, como a saúde, habitaçăo, educaç̧o, etc.

Os objetivos da intervençă profissional portanto, giram em torno da racionalizachlo do processo de prestaçăo dos serviços sociais e da assistencia social que, segundo MARTINELLI (1989, p. 87) possui uma funçăo ideológica de controle, determinada historicamente enquanto resposta da burguesia a ameaça social que decorre da acelerada expansáo da pobreza e da generalizaçăo da miséria, que agravam quer o processo de acumulação, quer o de legitimaçăo no capitalismo.

Com o desenvolvimento do estágio monopolista do capital e de acordo com o modo "fordista" de regulaçāo, foram criados os serviços sociais como forma indireta de remuneraçăo jấ que os salários percebidos pelos trabalhadores nảo têm o poder aquisitivo suficiente para suprir suas necessidades básicas de sobrevivência. $O$ capital necessita de trabalhadores ativos que dêem conta da pro-

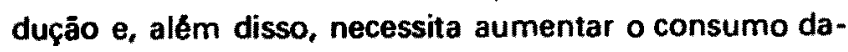
quilo que produz.

Segundo PRZEWORSKI (1991, p. 224), foi o "key. nesianismo" que forneceu os alicerces ideológicos e polfticos para o compromisso da democracia capitalista, e ofereceu a perspectiva de que o Estado seria capaz de conciliar a propriedade privada dos meios de produção com a gestāo democrática.

O Estado nacional considera que a Seguridade Social engloba a Saúde, a Previdência e a Assistência Social.

$A$ inserção dos serviços sociais na relação capitaltrabalho reflete as relaçōes antagónicas de classe e o assistente social, como técnico ao qual compete a administraçăo de serviços e beneflcios sociais ao trabalhador, realiza predominantemente um papel ideológico de perpetuação das relaçōes de trabalho.

"Assim, porque as relaçoes de trabalho se estabelecem logo sobre um fundo de relaçbes antagónicas de classe, a organizaçáo herárquica e o controle do trabalho aparecem sempre para o capital, como a condiçáo de toda produçăo e corno um fim em si. Săo incorporados nos métodos e nos instrumentos de produçăo e aparecem em seguida como necessidades técnicas do proprio processo de produçáo. É por isso que todos os que, acobertados pela competéncia técnica, săo chamados a supervisionar o desenvolvimento da produçáo, trabalham de fato para a perpetuaçáo da divisáo hierárquica e das relaçoes de produçăo capitalista". (GORZ, 1980, p. 235-236)

O trabalho exercido pelo assistente social tem a mesma determinação histórica do trabalho exercido pelos "tecnicos" de que trata o autor.

Embora a inserçāo da profissảo seja conjuntural ao seu campo de trabatho, ela se soma às demais profissōes técnicas do setor terciário, de serviços, quando se considera a finalidade última para a qual o sistema a criou.

A profissão apresenta um quadro térico-metodológico próprio e constrói instrumental técnico especifico para intervenção na realidade social.

Consideram-se como elementos componentes de 
todo processo de trabalho: o próprio trabalho, o objeto e 0 instrumental.

Quando se pretende colocar em queståo a competência profissional do assistente social, nāo se pode prescindir da constatação de que a natureza da profissáo interventiva sobre as demandas sociais reais e a proposta de açāo se dŜ, a partir da investigaçāo da realidade, da definiçăo do objeto e dos objetivos se operacionaliza pela determinação de um instrumental técnico que a viabilize.

Diante disso, torna-se fundamental a abordagem do instrumental utilizado na prática profissional do assistente social.

\section{2 - INSTRUMENTOS E TÉCNICAS-ELEMENTO COMPONENTE DO PROCESSO DE TRABA- LHO DO ASSISTENTE SOCIAL:}

O trabalho executado pelos assistentes sociais exige a definição de alguns instrumentos e técnicas a serem utilizados no cotidiano da prática profissional, visando as modificaçōes da realidade diagnosticada, propostas no plano de intervençāo. Tratam-se instrumentos de coleta dados, formulação de estratégias e táticas, formas de abordagem dos usuários das instituiçóes, e todo tipo de técnica que se coloque como elemento mediador entre a proposta e a açăo.

Analisar o instrumental utilizado pela profissāo, carece da configuraçāo de dois importantes momentos históricos que influenciaram na utilização das técnicas e dos instrumentos de intervenção.

O primeiro momento pode ser evidenciado historicamente no Brasil em 1967 quando um grupo de assistentes sociais se reúne para teorizar a profissão e faz claramente uma opçāo de intervençāo que privilegia a técnica na definiçåo e controle dos servicos sociais diante da demanda da realidade na época. $O$ momento emerge das propostas desenvolvimentistas assumidas pelo Estado no enfrentamento da "questăo social".

Nessa conotaçáó de Desenvolvimento, entende o Servico Social que o homem deve ser nele, simultaneamente, agente e objeto, em busca de sua promoçá humana num sentido abrangedor de modo que os beneficios náo se imitem a traços da populaçáo, mas atinjam a todos, propiciando o pleno desenvolvimento de cada um. Para a instrumentalidade da intervença do Servico Social no Desenvolvimento, fazse mister a elaboraçó de modelos que sistematizem a programacáo global elou setoriah. a thub do contribuigéo, apresenta-so este primeiro asquema de modelo de atuacáo do Servico Social: - Ideologia do Desenvolvimento Integral; - Mobilizaçio de Forgas Organizativas; . Capital - ro cursos humanos e materiais - :. Tócnica.
Face a aste modelo do atuacto sugere-se como funçáo $\theta$ atividade do Servico Social om uma escala de micro a macro atuacáo". (CBCISS, 1984, 0. 41-42)

A ideologia que permeou a sistematizaçăo da profissāo no Brasil centra-se, portanto, numa perspectiva de assegurar que os serviços sociais atingissem a todos os cidadāos, como forma de sanar o problema social e contribuir com o desenvolvimento social.

Uma entre outras assistentes sociais pertencentes a este quadro, VIEIRA (1976), elaborou na mesma época sua primeira produção teórica significativamente respeitada - "Serviço Social - processos e tocnicas", quando expōe uma proposta instrumentadora da intervençāo profissional do assistente social.

Considerados como processos de serviço social, o caso, o grupo e a comunidade, aborda técnicas e instrumentos especfficos a serem utilizados para cada processo.

Quando analisamos a proposta da autora, evidenciamos a leitura funcionalista que determina a sociedade como um todo organizado em partes, onde cabe ao assistente social ser um agente adaptador dos individuos, grupos e comunidades às situaçōes especlficas, visando as relaçōes harmoniosas dessa sociedade para atingir o bem estar geral.

O bom relacionamento proclamado, tem sentido ideológico de controle sobre a vida das pessoas e as visitas servem de fontes de coleta de informaçes que servem muito mais a uma investigação técnica $\theta$ orientaçōes de condutas do que propriamente cortesia.

Essa perspectiva modernizou-se historicamente, à luz da teoria sistêmica e VIEIRA (1976, p. 149, 178) faz revisäo do instrumental utilizado pelo assistente social dividindo-o em quatro grupos: 1 - Instrumentos psicologicos: 2 - instrumentos técnicos; 3 - instrumentos situacionais; 4 - instrumentos administrativos".

Quanto aos instrumentos psicológicos, considera que eles se referem ao uso profissional do "eu" lassistente sociall e o relacionamento com o sistema cliente. Sazo potencialidades inatas ou adquiridas e qualidades cultivadas por meio das quais o individuo se adapta ao mundo. A partir do "eu" profissional sáo desempenhadas atividades de compreensăo, nảo julgamento, aceitaçāo, envolvimento emocional e empatia com o cliente.

Para haver bom relacionamento entre o profissional e o "sistema cliente" lindividuo, grupo ou comunidade) é preciso desenvolver a comunicaçāo laceitaçăo, ansiedade, agressividade, dependência, racionalizaçăo, projeçāo, identificaçāo, resistência, participaç̄o, autoridade) o que leva 0 assistente sccial a trabalhar com diferentes fenómenos no relacionamento.

Como funcionário de uma organizaçăo social, delegada ao assistente social certa "autoridade" diante dos trabalhos que a mesma the determina e confia, os quais contribuem para com os seus objetivos.

É também uma autoridade considerada pela com- 
petencia, uma vez que seus conhecimentos e experiencias o tornam capaz de "ajudar" o sistema cliente.

A delegaçāo da autoridade somada à condiçảo de competéncia dăo ao assistente social controle moral e técnico sobre o sistema cliente. Portanto a proposta da autora apresentou-se modificada em sua forma (mais competente o técnica), porém continua a propiciar o exercicio profissional envolto pela autoridade do saber instituido sobre o usuário institucional.

Quanto à eleiçẫo do instrumental técnico, VIEIRA (1976) assume o conceito de técnica desenvolvido por AVILA:

"Técnica supóe uma iniciaçáo sistemática nos conhecimentos cientficos indispensáveis para resolver metodicamente os problemas práticos da aplicaçáo da ciência. uma maneira pratica especfica de utitizar instrumentos e/ou moios". (AVILA, apud VIEIRA, 1976, p. 166-173)

Assim considerada a técnica no caso do serviço social propóe como instrumentos: a entrevista, a reuniāo, a atividade, os recursos da comunidade.

O objetivo da profissäo se subdivide entre a conscientizaçāo e a participaçāo do sistema clĩente, sendo as técnicas utilizadas de maneiras especlficas, subdividindose em dois grupos: 1 - técnicas de constatação, explicação e compreensão; 2 - técnicas de intervençăo.

O primeiro grupo de técnicas lobservaçāo, documentação, estatistica, questionários), será empregado para conhecimento da situaçäo social problema do sistema cliente; bem como o contexto onde ela se insere.

O segundo grupo, tecnicas de intervençāo, pode ser dividido em tếcnicas que levem: 1 - à conscientizaçāo lesclarecimento, interpretaçāo, classificaçāo e avaliaçāo); 2 a açăo (apoio, incentivação, mobilização e orientação); 3 tócnicas que levem à organização da açăo (utilização dos recursos, dos meios, coordenaçāo, limitação e uso da autoridade).

Alêm dos instrumentos técnicos, VIEIRA (1976) acrescenta os instrumentos situacionais do serviço social, que se referem a dois tipos de situação em relação ao sistema cliente: a situaçăo face a face e a situaçāo grupal. Na situaçăo face a face prepondera a técnica da entrevista e na situação grupal, a reuniāo.

São colocados como objetivos desses dois tipos de instrumentos: 1 - Obter informaçôes do sistema-cliente ou de outras pessoas relacionadas direta ou indiretamente com a situaçāo-social-problema; 2 - dar informaçōes a estas mesmas pessoas; 3 - conscientizar o sistema-cliente quanto à natureza da situação-social-problema; 4 - levar o sistema-cliente a tomar decisōes e executá-las.

Alêm dos instrumentos psicológicos, técnicos e situacionais, o instrumental proposto por VIEIRA (1976) para a profissão, considera os instrumentos administrativos, que se referem à documentaçăo e providências diverses que fazem parte do estudo da administraçäo do serviço social.

A partir dessa proposta reformulada pela autora, analisa-se seu referencial teórico-metodológico como fundamentado na filosofia positivista, com tendéncias de intervençăo luz da teoria sistêmica de funcionamento da sociedade.

$O$ instrumental foi revisado porém, o sentido e a intencionalidade impressos $\partial$ intervenção continuam pautados em conceitos como os de autoridade e controle exercidos pelo profissional, técnico eficiente, sobre o sistema-cliente (indivlduos, grupos e comunidades) com o qual trabalha.

Com o surgimento do movimento latino americano chamado de "reconceituação do serviço social", surge • uma nova perspectiva teórico-metodológica para a profissāo.

Uma, entre outros teóricos adeptos deste movímento, CLARK (1974), elaborou uma proposta em relação ás técnicas a serem utilizadas pela profissão à luz do marco teórico chamado de método cientlfico ou ainda materialismo histórico dialético.

"Na busca destes caminhos, os trabalhos sociais determinam que todo método utilizado pela profissáo deve superar ou dissociar-se do marco ideológico funcionalista e positivista.

As técnicas utilizadas pelo Trabalho Social que atuam como instrumentos auxiliares da atuação profissional săo:

- técnicas para conhecer a realidade; - técnicas para regular a realidade; - técnicas para transtormar a realidade; - técnicas para mobilizar as massas; - técnicas para organizar e educar as massas; - técnicas para o planejamento e elaboraçăo de programas diagnósticos; - técnicas para apreciaçăo quantitativa da realidade; etc.

Estas técnicas, no entanto, năo são cobcadas para uso exclusivo do trabalho social, mas para todas as profissóes que se preocupam com a investigaça cientifica" (CLARK, 1974, p. 37-40)

A conotação dada às técnicas, pela autora centra-se na preocupação com a função social de cada grupo de técnicas, (transformar, mobilizar, regular, etc.), do que na preocupação em explicar o "como fazer", sob a ótica da competência técnica envolta pela postura de neutralidade. Tenta evidenciar o compromisso que o profissional deve ter com a clientela usuária da instituição e năo apenas com a própria instituiçāo. As técnicas nesta visāo, se colocam como instrumentalizadoras de uma perspectiva projetiva da profissão, que se colocasse a serviço do processo da transformaçāo social.

A proposta de CLARK (1974) ainda considera que o serviço social deva criar cada vez mais, novas técnias que se coloquem a seu serviço, como intrumentos eficazes nessa tarefa compromissada com a transformaçāo da realidade e das consciências das populaçóes usuárias das instituiçōes. 
"Podem ser criados diferentes tipos de técnicas, distintas das chamadas tradicionais, quais sojam:

- técnicas de inserçáo na realidade: todas aquelas que permitam situar a realidade, estabelecer nexos de relaçăo com pessoas e grupos (entrevistas, contatos, comunicaçăo de massa, educativas, grupais, etc);

- técnicas de obtençáo de dados: questionários participativos, observaçấo participativa, etc...;

- técnicas de registro de dados: diario de campo, relatórios de campo, cédula, etc..;

- técnicas de sistematização: tabulaçáo, informe, pre-diagnóstico, diagnóstico, etc..;

- técnicas de mobilizaçáo: motivaçấo, comunicaçăo de massa, circulares, boletins, diário, murais, platatormas de luta, etc...;

- técnicas de planejamento micro-social: programas, projetos, projetos especfficos, avaliaçáo, orçamentos, etc...;

- técnicas de organizaçáo: estudos e dossiés de grupo, dinámica grupal, técnica de debates, análise de debates, capacitaçăo grupal, etc..;

- técnicas de conscientizaçáo: circulos de cultura, dramatizaçăo, teatro, jomais, folckore, projeçбes cinematográficas, slides, etc..;

- outras (consideram-se outras técnicas necessárias de acordo com o proposito do trabatho, inclusive manter algumas técnicas tradicionais que continuam, diante da nova proposta, eficazes para os propossitos presentes a luz de uma nova orientaçâ)"." (CLARK, 1974, p. 42, 43).

A autora frisa que a mudança substancial deva ser na orientação dada ao instrumental, que a partir da nova proposta, deve ser colocado a serviço das classes dominadas, para sua libertaçäo e sua implementaçāo pela via do método cientlfico.

A inovação substancial nāo trata da elaboraçăo de novas técnicas para a profissão, mas antes de tudo, pōe em questão a intenção polftica que permeia os procedimentos profissionais.

A intencionalidade esta direcionada nāo ao controle e autoridade, mas ao resgate da condiçăo de sujeito do usuário das instituiçbes sociais, no processo de transformaçăo social.

Outro ponto evidenciado como diferenciado do modo tradicional de utilizaçâo do instrumental, a abordagem da clientela atendida, que antes se fragmentava, ora como individuo, ora como grúpo, ora como comunidade, e a partir da nova perspectiva passa a se considerar como pertencente a uma classe social.

Neste sentido, as técnicas perdem o caráter de interferência direta sobre a vida das pessoas, para se caracterizarem em instrumentos disponiveis aos próprios sujeitos, a partir de açóes sociais conscientes.
Tendo abordado as propostas de utilização do instrumental técnico pelo serviço social a partir das duas perspectivas históricas, pode-se concluir com KRUSE (1972) que a questāo operativa do instrumental técnico profissional năo pode ser trabalhada fora do contexto histórico de formação da profissão.

A eleiçāo de técnicas e instrumentos para a profissăo foi determinada historicamente pelas origens da formação profissional e pelas influências recebidas das ciências e disciplinas afins â sua área de atuação.

Assim sendo, as técnicas iniciais, assimiladas de açōes benevolentes, caritativas, religiosas (aconselhamentos, ajuda, visitas de cortesial, foram se somando às funçōes paramédicas exercidas pelos assistentes sociais (suporte aos serviços de saúde), assim como funçóes relacionadas ao Direito ou a Sociologia (prestação de informaçōes, instruçăo de inquéritos, levantamentos de dados sócio-económicos, pesquisas).

Com a influência da corrente psicanalítica, novas tecnicas foram introduzidas (relacionamento, coordenação de grupos, escalas sociométricas, motivaçăol e a partir delas, sob a orientaçāo desenvolvimentista na década de sessenta, foram incrementadas têcnicas de Sociologia e de Psicologia Social (investigação de campo, cooperativas, organização, ajuda mútua, técnicas de liderança, audiovisuais, etc...), alêm da incrementação de técnicas de Pedagogia Social (conscientizaçăo, educaçåo popular).

Por fim a influência da Administraçảo e do planejamento (técnicas de racionalizaçāo, controle) tiveram influência marcante na institucionalizaçảo da intervenção profissional. A partir do estágio monopolista do capitalismo a emergência dos serviços sociais tem apresentado novas demandas que colocam em questăo a natureza da profissāo.

Este breve apontamento sobre as influencias sociais, técnicas e cientlficas, que sofreu a profissāo no processo de instrumentalizaçāo técnica para a intervençăo na realidade social, serve para analisar o movimento que permeia este estudo sobre a questão da competência profissional do assistente social.

\section{3 - A QUESTÃo dA COMPETÉNCIA TÉCNICA PARA O ASSISTENTE SOCIAL - A POLÉMI- CA E O DILEMA ${ }^{3}$}

É na ciéncia racional das organizaçóes que o conceito de competência técnica, é fundamentado historicamente, uma vez que através dela: o conhecimento cientifico passa a ser utilizado para reduçăo dos custos da produçăo, produtividade acúmulo do capital; $e_{\text {, }}$ a técnica, instrumento eficaz na obtençăo dos objetivos que se voltam para a extraç̆o da mais valia.

A idéia de "organizaçăo" 6 vinculada historiçamente ao processo de "burocratizaçăo" de todas as esferas da vida humana, inclusive nas manifestaçōes culturais. 
A burocratização dos cargos e da sua hierarquização legaliza a dominaçăo que certos grupos sociais exercem, justificada pelos imperativos racionais e técnica do "desenvolvimento social".

CHAUI (1982) trabalha a questāo da burocratização das organizaçōes modernas cujos cargos e postos ocupa* dos pelos homens determinam suas competéncias especlficas, diante da existência de um sistema de autoridade fundado na hierarquia.

"O real, a ação, e o conhecimento ficam consubstanciados, identificados. No intenior dessa 'substância', is to é, a organizaçăo, os homens já encontram pré-traçadas as formas de açấo cooperaçăo 'racionais', ou seja, aquelas que thes serăo permitidas ter... A Ciência da Competéncia tornou-se bem vinda e o conhecimento enquanto competéncia institulda e institucional torna-se uma arma para um tantástico projeto de dominaçấo e de intimidaçăo social e polticica afirmando o poderia daqueles a quem a burocracia $e$ as organizaçóes determinam previamente autoridades a saber. (CHAUI, 1982: 11-13)

Assim colocada, a competência se materializa como um projeto de dominaçäo pelo saber e de intimidação daqueles que năo sabem.

O saber instituido do assistente social tem caracterizado a sua competência técnica diante das organizaçōes de assistência social, para enfrentamento dos efeitos provocados pela "questão social", no sentido de amenizar as distorçōes do sistema capitalista. Eis al o projeto de dominaçăo materializado na forma de nossa profissāo.

Portanto, a profissão surge no ambiente da introduçāo de elementos cientificos nas relaçōes humanas postas no processo produtivo, quer diretamente na organização, quer em sua extensāo no espaço de reproduçāo das condiçōes de vida.

Ela se insere, pois, no espaço de normalizaçāo e regulaçăo da vida e das relaçōes sociais do trabalhador e, como tal, se comporta no ideb́rio racionalizador da burocracia. Nesse campo da regulaçăo social em qualquer ação institucionalizada, o assistente social deve ser um agente de capacitaçāo psico-social para o trabalho. Essa capacitaçāo se dâ através da distribuição de meios, acessos, beneficios, e também, através da retórica cuja pedagogia pode ou não ser espaço de dominação.

Mas o assistente social não trabalha somente com o assalariado; na realidade trabalha com as condiçōes de sobrevivência o que vai incluir tanto o trabalhador ativo como o de reserva, pondo-se a questăo de como fazê-lo subsistir, e de como adestrá-lo para a absorçäo no campo de trabalho.

Como exemplo, o assistente social erientado em sua formaçăo a desenvolver o processo de conscientizaçåo, em sua relaç̧ăo profissional com o usuário, o "clien. te" dito vulgarmente. Isso suporia trabalhar o problema, a queståo do ponto de vista do usub́rio, porém para a instituiçāo a quem presta os serviços, a expectativa 6 de rea- lizar o enquadramento do usuário às normas institucionais. Quanto mais harmonia e sem conflitos for essa adesăo das pessoas às normas instituldas, maior competência será institucionalmente atribulda ao profissional, o que não significa corresponder à expectativa do demandatário. Na verdade, evidencia-se um duplo posicionamento no papel profissional em que o assistente social co-autor. Para a população, aquele que ouve, que dialoga, que explica, que justifica e informa. Traduz-se na esperança do usuário de ser incluldo nas normas institucionais. $\dot{E}$ alguêm que parece estar próximo aos que demandam os serviços sociais, reconhecendo sua miséria, dando-lhe a mão e compartilhando com ela, - ao menos na retórica - as injustiças dos critérios de inclusāo. Por outro lado, existe o papel assumido perante a instituição para a qual o assistente social 0 interlocutor que sabe se movimentar na linguagern do usuário, que entende a questão da pobreza, e ameniza no cotidiano, o sofrimento da população. Nesse processo de seleção da pobreza, o profissional analisa o processo de gestäo e controle como seu principal intérprete. Por vezes, no entanto, aliena-se nesse processo, atê por uma questāo de sobrevivência do emprego.

A criação, distribuiçăo e controle dos beneffcios e serviços sociais às populaçōes carentes, contribuem para a diminuição aparente das desigualdades sociais e redução dos conflitos, e deste modo, sustentam e mantêm as condiçōes básicas de persistência do sistema capitalista de produção.

O saber instituldo do assistente social caracteriza sua competência têcnica diante das instituições para redução do conflito e enfrentamento da questão social, no sentido de amenizar as distorçōes do sistema capitalista. $\mathrm{Na}$ expectativa institucional, competente $e$ aquele profissional eficiente no desenvolvimento de suas atribuiçōes. Essas atribuiçōes, no entanto, são determinadas pelo sistema hierárquico da organizaçāo, onde a competência tem sentido ideológico, embora mistificado, como uma arma para o projeto de dominação de classe, que autoriza o tipo de "saber" a ser institucionalizado como competente.

Diante disso, o que se percebe que esta idéia de competência pode ter um sentido politico-ideológico na manutençăo do sistema vigente, pela classe dominante. Ao mesmo tempo pode-se considerar que a competência possa ter um sentido polltico inverso, ou seja, comprometido e, portanto, direcionado para a ruptura da condição de subalternidade em que se encontra o usuário dos serviços sociais.

MELLO (1985) desenvolve esse tema - o sentido político da competéncia profissional, na área da Educaçāo - analisando o saber privatizado pela classe dominante e o sentido politico que pode ter a prática docente utilizando a competência técnica como mediação:

"O sentido polfico da prática docente que eu vabrizo, se realiza pela mediaçáo da competencia técnica e constitui condiçăo necessária, em- 
bora náo suficiente, para a plena realizaçăo desse sentido polfico da prática docente para o professor". (MELO , 1985, p. 44)

Competencia técnica para a autora evidencia o "saber fazer bem" e essa competência é importante para um projeto politico intencional quando se pretende transformar as relaçöes sociais na realidade. Importante notar que a técnica nāo é considerada como um fím em si mesma, mas como mediação. Nesse caso, não se ratifica a técnica, mas se usa como meio.

O conceito de competência cria nova dimensão:

"a competência que privilegio nesse trabalho, portanto, inclui o saber técnico, começa muito aquém deste e o uttrapassa. Mas năo o exclui, isto é importante, ao contrário, subentendo-o como mediador de sua própria superaçăo". (MELLO, 1985, p. 55). "...Se essa competéncia nåo existe, será preciso criáta". (MELLO, 1985, p. 56)

A autora trabalha a questão da competência da escola, considerando que, historicamente, ela tem assumido a funçāo seletiva e elitista diante da sociedade de classes. Assim sendo, elimina pelo fracasso escolar, as crianças de origem social económica desfavorecida, assegurando e privatizando o "conhecimento" as classes medias.

Em relaçâo ao Serviço Social, a competência técnicas tem assumido papel semelhante, ou seja, cabe igualmente ao profissional a seleção da clientela, porém com uma diferença: a seleção que compete ao assistente social fazer, é a dos mais necessitados para a distribuição dos serviços institucionais. A princípio, sāo seus clientes prioritários "os eliminados" no caso da escola. Assim, o elitismo possivel no serviço social não é pela exclusāo, mas pela forma de inclusão.

Nesse sentido, a inclusảo ou acesso privilegia as piores situaçōes pelo mérito da necessidade. A primeira vista, aqui se pōe uma açāo competentemente justa na distribuição. Ocorre, porém, que essa distribuição é, na verdade, fracionadora da miséria enquanto escala neces* sidades e sobreleva situaçōes conjunturais e até mesmo circunstanciais de aprovaçăo. Este quadro faz do trabalho técnico uma equivaléncia ao "pronto socorro médico", onde a competência se dá pela prontidăo da presença, agilidade de uso de instrumental e de referência da rede de serviços, para processar o encaminhamento ao sistema suporte ou de referencia.

“... Integrando-se a uma grande diversidade de instituiços que se definem a partir de prátcas sociais e assistenciais determinadas, o Serviço Social tem por clientela especializada os segmentos mais carentes que tem acesso a elas". (IAMAMOTO \& CARVALHO, 1985, p. 317)

Enquanto os educadores realizam a seleçăo entre os setores privilegiados da sociedade, os assistentes sociais, inseridos nas instituiçōes de atendimento às necessidades básicas, realizam a seleção dos setores explorados da mesma sociedade. Trata-se da seleção dos considerados mais miseráveis entre os necessitados sociais.

Resta indagar quanto à escala de valores e a intencionalidade polltica que informa o conceito de competência profissional nesse processo de inclusão/exclusão dos usuários das instituiçōes sociais.

A noção de competência vai alêm da manipulação de técnicas lo "fazer" no sentido tarefeiro do cumprimento da funçāol quando se leva em conta a dimensāo do compromisso polftico da profissão e o papel do profissional para além do instituldo.

A compreensão da competência poderá passar do imediatismo da incrementação da técnica, que vê a profissão em si, para a compreensão ampliada que considera o processo histórico que leve a profissăo a assumir compromisso com as alteraçōes da realidade de vida dos usuários, no sentido da universalizaçāo dos direitos sociais.

A posição ocupada pelo serviço social na divisão social do trabalho determina para o assistente social a regulaçāo social e salarial do trabalho e o papel de prestador de serviços sociais, contratado por uma instituiçāo que possui normas prê-estabelecidas de atendimento. Por outro lado cabe ao mesmo profissional atender a uma demanda posta pelo usuário da instituiçăo que o contrata. Este papel de mediador entre interesses institucionais e interesses dos usuários coloca a questão da competência sob dois ángulos. Além do reconhecimento da competência pela ótica institucional, existe o reconhecimento da competência pela ótica do usuário. Eis então o dilema da competência profissional do assistente social.

\section{4 - CONCLUSÃo}

O assistente social é um trabalhador técnico, contratado, cuja prática se insere numa instituição. A competência tem sua lógica, primeiro, no interior da própria instituição. A questão que se coloca, a partir de entảo, é como o profissional se posiciona nesses limites: de modo subordinado, ou com possibilidades de ultrapassá-los. Sendo um trabalhador técnico, o assistente social tem relativa liberdade face ao próprio trabalho e, ainda além, exerce poder pelo trabalho. Esse poder circunscreve-se ao domínio de dados de realidade que envolvem a questāo das políticas sociais e, em especlfico, a assistência social.

O que se dá característica de profissional ao assistente social e sua inserção formal no espaço das políticas sociais, na relação capital-trabalho. Nela o Estado tem papel determinante para regular as condiçôes de reproduçāo das relaçóes sociais e neutralizar os conflitos provenientes da questāo social.

O assistente social se coloca nesse processo como um dos agentes técnicos, detentor de um poder especifico na prestaçăo dos serviços sociais e, compondo a divi- 
são sớcio-técnica do trabalho, the sāo atribuldas funçōes e papéis.

A competência profissional do assistente social tem como território um dilema: se, por um lado a prática profissional institucionalmente gestada para ser controladora, disciplinadora de normas, selecionadora de critérios excludentes da pobreza, por outro lado, ela se traduz num processo de possivel distribuição e configuração de direitos sociais, podendo o técnico assumir compromisso com os usuários institucionais, no sentido da conquista, ampliação e universalização dos seus direitos.

Tal compromisso, não implica necessariamente, em que o profissional assuma um posicionamento contraposto ao sistema vigente, pelo contrório, ele contribui para o aprimoramento da regulaçāo e do controle social, quer no ámbito da legitimação, quer da acumulaçāo capitalista.
A competéncia profissional portanto, se coloca na interseção entre a consciência dos limites e o compromisso com o possivel - atender a demanda real.

Faz-se necessária, para tanto, a capacidade de arr:pliaçāo da situaçāo emergente, para além do cumprimento da tarefa institucionalmente atribuida. Esse movimento enfoca a questāo de direçāo política da prática profissional e, como tal, destaca o protagonismo de seus atores, principalmente do usuário dos serviços sociais, enquanto sujeito do processo e cidadāo que tem direitos e luta por eles. A satisfação das necessidades básicas é a primeira condiçăo para que o usuário seja sujeito de sua historia. A partir dessa condição, cabe ao assistente social, dentre outras funçōes, o papel de socializador das informaçōes necessárias para instrumentalizar o sujeito/protagonista, na luta pela conquista dos seus direitos sociais.

ALVES, J.M. The issue of the technical competence for the social worker. Semina: Ci. Soc./Hum., Londrina, v. 13, n. 3, p. 148-157. Sept. 1992.

ABSTRACT: This article deals with the social work "professional competence", enphasizing its tecnical and political dimension. Concerning to the social role and the professionals insertion on the socialthechnical division of labour, situated on the services section of the current monopolist stage on capitalism; the estabilished knowledge of the social work within the welfare organizations, begining with the attribuitions, instruments and technics; the contradiction of a profession wich has employment links with organisms created by the State and by the Capital, but should give services to subalternized users and the actual meeting of the social demand put in by the users and the issue of the professional obligation with the rupture of their condition of poverty and subordination.

KEY-WORDS: Professional competence; Social, Worker; Labour; Instruments; Technical, Political, Social; Services; State, Capitalism, Social issues

\section{REFERÊNCIAS BIBLIOGRÁFICAS}

ALVES, Jolinda de. Competencia Profissional: dllema do Assistente Soctal. SAo Paulo, 1992. 233p. Dissertaçto (Mestrado) Puc.

BRAYERMAN, Harry. Trabalho e capital monopolista: a degradaça do trabetho no éculo $X X$. 3. ed. Rlo de Janeiro: Zahar, 1981 .

CBCISs. Tecrizaça do Servico Sccial; Arexa, Terescpolls, Simart. Flo de Janolro: Aglr, 1984.

CH.AUI, Marlena. Cuttura $e$ Democracia: o discurse competente e outras talas. S5o Paulo: Moderna, 1982.

CLARK, Marla AngÉlca Gallardo. La praxis del Trabajo Social en una dirección ciontfica. Buenos Ahres: Lubsitu Ecro, 1974.

Conz, Andr6. Crtica da divisáo do trabalha Sto Paulo: Martins Fontes, 1980.

IAMAMOTO, Marilda \& CARVALHO, Raul. Relacbos Socials o Servico Social no Brasil: esboco tie uma Interpretefto metodologlea. 3. ed. STo Pauio: Cortez, 1905.

KARSCH, UM.S. O Servico Social na era dos Servicas. Sto Paulo: Cortiva, 1887.
Social Buenos Alres: Ecro, 1972, 167p.

MARTINELLI, Maria Lücla. Servico Social: Identidade e aller acto. Sáo Paulo: Cortez, 1989.

MARX, Kari. O Capital: critica de economla politca. Rlo de Janeiro: Civilbaçio Brastielra, 1987.

MELLO, Gulomar N. Magistério de $1^{\circ}$ Grau: da competencla ténica ao compromisso polltco. 5. ed. Sao Paulo: Cortez, 1985.

NETO, Jose Paulo. Auboracia Bunguesa e Serviço Soclal Săo Paulo: Cortaz, 1991.

OFFE, Claus. Capitalismo desorganizado. Sto Paulo: Brasillense, 1987.

PRzEWORSKI, Adem. Capitalismo e socialdemocracia Sto Paulo: Companhla de Letras, 1991.

VEFA, Balbina O. Servico Social: processos e técnicas. Rlo de Janeiro: Aglr, 1976.

Metodologia do Servico Sociat contribrulftio para a sua elaboracto. Rlo de Janelro: Aglr, 1979. 